\title{
Prevalence of HIV and Treponema pallidum infections in pregnant women in Campinas and their association with socio-demographic factors
}

\author{
Obstetrics and Gynecology Department, Medical School, University of Campinas - Campinas, Brazil
}

\begin{abstract}
The anonymous seroprevalence of HIV and syphilis was studied by collecting umbilical cord blood samples from 5,815 women who gave birth in Campinas' hospitals throughout a six-month period. ELISA and Western blot were used for HIV, and VDRL and TPHA for Treponema pallidum screening. While maintaining the anonymity of the women, information was recorded on the hospital of origin, divided into university (public) and private hospitals, as well as on the form of payment (social security, private insurance or direct payment), age, marital status, education, employment and place of residence. Seroprevalence was 0.42 percent for HIV and 1.16 percent for syphilis. There was a significant correlation between a positive reaction to the two infections $(p=0.02)$. After univariate and logistic regression analysis, only university hospitals were shown to be associated with seropositivity for HIV, whereas the same variable and an older age were associated with syphilis. All positive reactions were found either in public hospitals or among social security patients treated at private institutions. The conclusion was that HIV infection is becoming almost as prevalent as syphilis among this population, and affects primarily the lower socio-economic strata. This suggests that routine, voluntary HIV serology should be considered and discussed with patients during prenatal or delivery care whenever a population shows a seroprevalence close to or greater than 1 percent.
\end{abstract}

UNITERMS: Human immunodeficiency virus. HIV, prevalence women, gestation. Umbilical cord blood.

\section{INTRODUCTION}

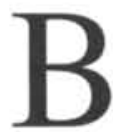
y mid-1991, a total of 371,802 AIDS cases had been reported worldwide; 18,113 of these were in Brazil, which ranked third in number of cases. ${ }^{52}$ The spread of the epidemic has been very rapid throughout the world, but has not followed the same model in every country. The identification of several epidemiologic

\author{
Address for correspondence: \\ Eliana Amaral \\ Divisão de Obstetrícia do CAISM - UNICAMP \\ Rua Alexander Fleming, 101 \\ Campinas/SP - Brasil - CEP 13081-970
}

patterns has contributed to a better understanding of women's participation in the spread of the disease.

Epidemiologic pattern Type I, found in the United States and in some areas in Latin American, corresponds to populations in which homosexual men are the most affected group, followed by intravenous drug users and a small number of women. Type II pattern is found in Africa and the Caribbean, with predominantly heterosexual dissemination and no difference in prevalence between men and women. Pattern III refers to countries with low AIDS prevalence even among groups considered high risk. ${ }^{40}$ Such patterns, however, can change with time, giving rise to an intermediary pattern Type I/II, found in regions where initial dissemination was among homosexuals and drug users, but where the incidence of 
the disease has been expanding through heterosexual transmission..$^{41}$ The World Health Organization considers Latin America, including Brazil, to be part of this intermediate group. ${ }^{36.39}$

According to information from the Brazilian Ministry of Health, the first male AIDS case in Brazil was reported in 1980 , but the first female case was not reported until 1983. In 1984, there was one infected woman for every 124 men, but in 1993 the ratio was 1:4. ${ }^{12}$ The evolution of AIDS distribution among Brazilian women has shown a decrease in infection through blood and blood products, but a progressive increase in infection by heterosexual contact, which today is the main mechanism for the transmission of HIV infection (Fig. 1).

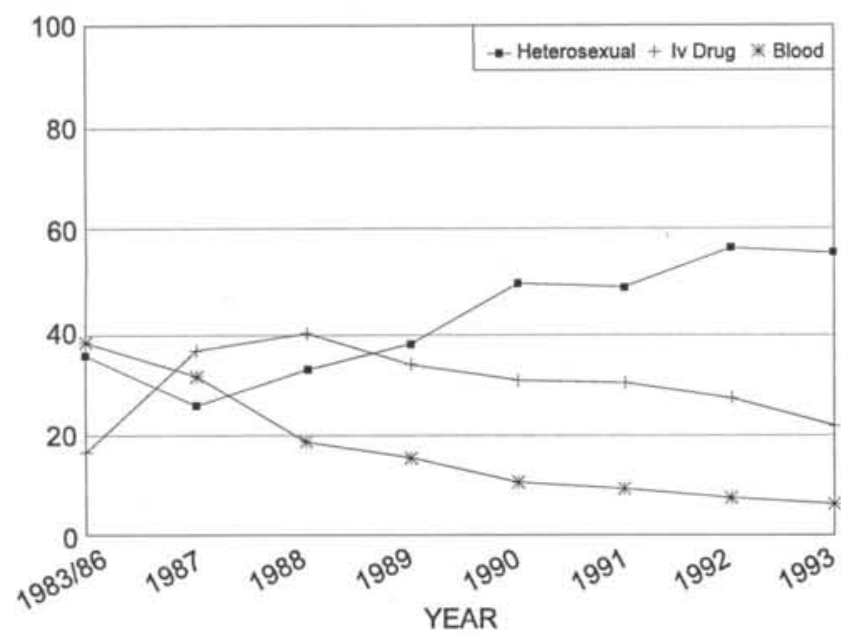

The immediate consequence of the higher prevalence among women is the vertical transmission of the infection to their children in a proportion that varies from 12.9 to 39 percent. ${ }^{9.24 .25 .45 .49}$ In Brazil, during the first half of 1993, vertical transmission represented 87.9 percent of all pediatric AIDS cases, whereas up to 1986,78 percent of HIV infections among children had been acquired through blood. ${ }^{12}$

Knowledge about the dimension of the epidemic is required to educate the population to adopt preventive measures, and provides the basis for sensitizing those who are politically responsible to make decisions which support control programs. This knowledge is also required for the evaluation of the impact caused by control measures. The indicator commonly used to assess the dimensions of the epidemic is the number of AIDS cases reported to health authorities. Nevertheless, such methodology affords only a late insight into the dynamics of the infection, as the numbers obtained refer to individuals who had been contaminated several years earlier. ${ }^{6}$
Prevalence studies of HIV infection constitute a more efficient method to evaluate the dimension of the epidemic and to follow its dynamics, providing global and updated information on contamination levels, which can then be applied to several population groups. ${ }^{6.48}$ Their repetition in relatively stable population groups through so-called "sentinel surveillance," provides a long-term view of the evolution of the epidemic. The multiplication of these "sentinel surveillance" studies permits efficient, swift and economical screening, as well as a monitoring of the infection..$^{20.47}$

The prevalence of the infection among women may be a good indication of the situation among the general population when non-selected groups are evaluated. The most comprehensive and practical way to reach unselected women is to perform serologic tests on patients attending prenatal clinics or at birth. ${ }^{29,33.38}$

Another reason for investigating the prevalence among delivering women is the risk of contamination for health professionals. ${ }^{15.16}$ Prospective studies of the risk faced by health professionals exposed to seropositive blood has shown a 0.3 percent rate of seroconversion after accidents with contaminated needles or cutting instruments, and no seroconversion after exposure of the mucosa. ${ }^{30}$

The professional assisting at a birth is exposed to much larger quantities of blood and other body fluids than most surgeons in non-obstetric procedures. Therefore, prevalence data on syphilis and HIV among pregnant women is also useful to highlight the need to take preventive measures. This applies to hospital management, to ensure the adequate provision of equipment, and to doctors and nurses, so as to educate them to take protective measures.

In Brazil, the medical literature shows a prevalence ranging from 1.0 percent to 3.75 percent in prenatal patients/delivering women in specific population groups,

\begin{tabular}{cccc}
\hline \multicolumn{4}{c}{$\begin{array}{c}\text { Table 1 } \\
\text { Proportion of valid samples to total } \\
\text { births by hospital }\end{array}$} \\
\hline Hospitals & $\begin{array}{c}\text { Samples } \\
\mathrm{n}\end{array}$ & $\begin{array}{c}\text { Deliveries } \\
\mathrm{N}\end{array}$ & $\mathrm{n} / \mathrm{N}$ \\
& 759 & 1,740 & 66.58 \\
\hline 1 & 1,380 & 1,602 & 86.14 \\
2 & 1,186 & 1,526 & 77.72 \\
3 & 725 & 794 & 91.31 \\
4 & 1,765 & 4,608 & 38.30 \\
5 & 5,815 & 9,670 & 60.13 \\
\hline
\end{tabular}


selected from where there is a high concentration of women presenting high-risk behavior for HIV infection. ${ }^{19.23 .43}$ At CAISM, the Women's Hospital of the State University of Campinas (UNICAMP), HIV infection was diagnosed during pregnancy in 0.47 percent of women delivering between September 1988 and December 1990. However, the actual prevalence was unknown, as serologic tests were performed only on women with known risk factors for HIV infection. ${ }^{2}$

Routine testing creates other problems, as the worldwide ethical norm for HIV infection screening establishes that the individuals to be tested should give their informed consent whenever identified by the person requesting the test. ${ }^{1.14 .18}$ Prevalence studies with identified subjects who agree to be tested lead to a underestimation of up to 50 percent, as a consequence of the selfexclusion of individuals at higher risk. ${ }^{22.30 .31 .50}$ The recommended ethical procedure for conducting random seroprevalence studies is to carry out anonymous serology, both on the part of the individual being tested and on the part the researcher, in a double-blind study ${ }^{3.6 .47 .48}$ This study design is considered ethical, because the blood sample becomes the object of the study, as the identity of the patients is unknown. This methodology has already been used in several countries, ${ }^{27.30,33.50}$ and is recommended by international organizations dealing with AIDS control after careful consideration of its advantages and disadvantages. ${ }^{38,47.48}$

The main advantage of this method is that it provides a more accurate evaluation of prevalence. At a time when few physicians pay proper attention to HIV infection, we judged raising awareness on the actual prevalence to be a priority that requires the adherence to methodology internationally recommended for this purpose.

The development of this study in Campinas was justified because the city was ranked ninth in absolute numbers and seventeenth in AIDS incidence coefficient, ${ }^{12}$ which placed the city in an intermediate situation among Brazilian urban centers. A parallel study on T. pallidum infection was added with the goal of comparing the prevalence of the two diseases, considering also that syphilis serology is part of the standard prenatal routine recommended by the Ministry of Health. ${ }^{10}$ This has the additional purpose of studying lues seropositivity as a risk factor for HIV infection.

\section{SUBJECTS AND METHOD}

A cross-sectional study was carried out between April 1 and September 30, 1991. Umbilical cord blood samples were collected in all deliveries occurring at the five hospitals registering the highest number of obstetric cases in Campinas ( 83 percent of deliveries). Three of the maternity hospitals are part of private or philanthropic organizations, and the other two are university hospitals, which make up part of SUS (Public Health System). Samples were collected during all births, without any selection criteria. Therefore, all types of patients were included, from those whose expenses were covered by SUS to those who had private health insurance or paid directly. The clinical boards of directors and the hospitals' ethics committees approved the development of the study after evaluating the proposal.

Umbilical cord blood samples $(10 \mathrm{ml})$ were collected without the addition of any anticoagulant, in all births, independent of the form of delivery (vaginal or by Caesarean section). The patients' initials, date and time of delivery were written on adhesive labels, with specific serial numbers for each hospital printed on the same label. Samples identified only by the label were collected daily by a research assistant from the five hospitals and delivered for serologic testing to the Hemocentro - Campinas, located at the State University of Campinas (UNICAMP).

An ELISA test (Abbot HIV I EIA, manufactured by Abbott Laboratories in Brazil) was carried out on each sample, followed by Western blot (Du Pont) whenever ELISA results were positive or inconclusive. Western blot was considered positive when positive results were found for bands p 24, p 31 , gp 41 or gp 120/gp 160, according to Biotech du Pont, criteria corroborated by the U.S. Food and Drug Administration. ${ }^{17}$ Screening for T. pallidum infection was conducted by VDRL quantitative test (Boehring), and all positive samples were tested for confirmation by TPHA (Biolab).

In the meantime, research assistants collected epidemiologic data from hospital records, removing any personal identification which could tie serology results to specific patients. To protect anonymity, only numerical identification was kept.

Dependent variables studied were: HIV infection and T. pallidum infection. Independent variables studied were: type of hospital (university or other); mode of payment for hospital bill (meaning how hospital and medical costs were covered); age; marital status; education; professional occupation; and city of residence.

All information was recorded on a special form. All forms without the serology results were excluded from the analysis. When serology results did not have the corresponding form with information on the independent variables, they were used only to estimate the general prevalence of the two infections (113 cases). Results of 
Table 2

Number of blood samples lost to analysis, by reason

\begin{tabular}{lrc}
\hline Reason & ELISA & VDRL \\
\hline - hemolysis & 693 & 693 \\
- insufficient material & 15 & 15 \\
- plasma formation & 0 & 19 \\
- broken vessel & 6 & 6 \\
\hline Total samples lost & 714 & 733 \\
\hline Valid samples & 5,101 & 5,082 \\
\hline Total samples collected & 5,815 & 5,815 \\
\hline
\end{tabular}

serological tests were entered into a IBM-PC computer using the DBase III Plus program; statistical analysis was carried out on the SPSS-PC program. Univariate analysis was concluded using dichotomized variables through the Q-square test and, when necessary, through the Yates and Fisher correction procedures. Multiple analysis was carried out using the logistic regression technique.

\section{RESULTS}

During the period of sample collection there were 9,209 births. However, because of failures in sample collection, only 5,815 blood samples were obtained, corresponding to 60.13 percent of all deliveries. The number of births, samples collected, and resulting proportion by hospital are shown in Table 1 .

More than 10 percent (714) of the samples were rejected for different reasons. Spontaneous formation of plasma in place of serum rendered 19 samples adequate for HIV serology, but not for T. pallidum. Consequently, 5,101 valid samples were selected for the ELISA test and 5,082 for the VDRL test (Table 2).

Table 3

Seroprevalence for HIV and T. pallidum by hospital

\begin{tabular}{crcc}
\hline Hospitals & $\begin{array}{c}\text { HIV } \\
\mathrm{n}(\%)\end{array}$ & $\begin{array}{c}\text { T. pallidum } \\
\mathrm{n}(\%)\end{array}$ & $\begin{array}{c}\text { Ratio HIV/ } \\
\text { T. pallidum }\end{array}$ \\
\hline 1 & $4(0.6)$ & $13(1.9)$ & $1: 3$ \\
2 & $12(1.0)$ & $24(2.0)$ & $1: 2$ \\
3 & $3(0.3)$ & $9(0.9)$ & $1: 3$ \\
4 & $0(0.0)$ & $3(0.5)$ & - \\
5 & $2(0.1)$ & $10(0.7)$ & $1: 5$ \\
Total & $21(0.4)$ & $59(1.2)$ & $1: 3$ \\
\hline
\end{tabular}

Table 4

Correlation between seropositivity for HIV and T. pallidum

\begin{tabular}{cccc}
\hline HIV & \multicolumn{3}{c}{ T. pallidum } \\
\cline { 2 - 4 } & Positive & Negative & Total \\
\hline Positive & $2(30 \%)$ & $18(0.4 \%)$ & 20 \\
Negative & 57 & 5,004 & 5,061 \\
Total & 59 & 5,022 & 5,081 \\
\hline
\end{tabular}

$\mathrm{p}=0.02$ (Fisher's test)

Twenty-two positive and five inconclusive results were found by the ELISA method for HIV. Twenty positive and one inconclusive ELISA-samples were confirmed as positive by the Western blot test. In the non-specific test for T. pallidum, 61 reacting samples were found, with quantitative VDRL less than or equal to one-eight. The specific proof confirmed the positivity of 59 samples, with evidence that the remaining two were false-positive.

Thus, the HIV seroprevalence found in the total collection of samples was 0.4 percent or 4 per 1000 , varying from 0 percent to 1.0 percent among participating hospitals. General seroprevalence for $T$. pallidum was 1.2 percent, varying from 0.5 percent to 2.0 percent. The highest prevalence was observed in university hospitals, and no HIV infection was detected at the one hospital which attends only private patients and those with private health insurance (Table 3 ).

There was a significant correlation $(\mathrm{p}<0.02)$ between seropositivity for syphilis and HIV. HIV infection prevalence was seven times higher in positive $T$. pallidum samples ( 3.0 percent), than in the negative $T$. pallidum group ( 0.4 percent) (Table 4$)$. The univariate analysis showed a correlation of both infections with university hospital and SUS payment mode; there also was a correlation with age over 24 for $T$. pallidum, and with the absence of a marital union for HIV (Table 5). No HIV seropositive samples were found among private patients or those who had private health insurance; the 21 seropositive samples were found among patients using SUS. Multiple regression showed, for both infections, a correlation with university hospital care and, for syphilis only, a correlation with older age (Table 6).

\section{DISCUSSION}

The 0.4 percent HIV seroprevalence found among childbearing women in Campinas can be considered low, 
Table 5

Summary of univariate analysis according to variable category

\begin{tabular}{llcccc}
\hline & & \multicolumn{3}{c}{ HIV } & \multicolumn{2}{c}{ T. pallidum } \\
\cline { 3 - 6 } Variables & Categories & Prevl. (\%) & $\mathrm{p}$ & Prevl. (\%) & $\mathrm{p}$ \\
\hline Type of & University & 0.8 & 0.0001 & 2.0 & 0.0001 \\
Hospital & Other & 0.2 & & 7.0 & \\
Mode of & SUS & 0.6 & 0.006 & 1.6 & 0.0005 \\
Payment & Other & 0.0 & & 0.3 & \\
Age & $\leq 24$ & 0.4 & 0.831 & 0.9 & 0.045 \\
& $\geq 25$ & 0.4 & & 1.5 & \\
Marital & In union & 0.3 & 0.037 & 1.1 & 0.244 \\
Status & Other & 0.8 & & 1.6 & \\
Education & 4 or less & 0.3 & 0.589 & 1.4 & 0.148 \\
in Years & 5 or more & 0.5 & & 0.9 & \\
Occupation & Yes & 0.3 & 0.534 & 1.1 & 0.499 \\
& No & 0.5 & & 1.3 & \\
Residence & Campinas & 0.4 & 0.879 & 1.2 & 0.803 \\
& Other & 0.3 & & 1.1 & \\
\hline
\end{tabular}

Prevl. $=$ Prevalence

while 1.2 percent for $T$. pallidum is classified as intermediate. ${ }^{51}$ The study has shown, however, great inequality in the distribution of cases; HIV and T. pallidum prevalence in university hospitals was twice as high as in the total of the samples (close to 1 and 2 percent, respectively). This classified them as having intermediate to high rates of these infections. The same ratio of one HIV to three T. pallidum infections was observed, with minor variations, in each hospital and in the entire collection of samples.

The evaluation of the prevalence found in this study should take into consideration that the precision of umbilical cord blood screening in the assessment of maternal serologic condition is questionable. Its accuracy for HIV infection has not yet been studied. As for syphilis, RAWSTROM and BROMBERG ${ }^{44}$ compared serology in maternal, umbilical cord and neonate blood, using the rapid plasma reagent (RPR). These authors found 33 percent of false-negative results in cord blood compared to maternal infection. On the other hand, 2 percent of the cord blood samples were positive while the maternal samples were negative. The same proportion of false-negative results for syphilis, in cord blood, had been found by MILLER et al. ${ }^{37}$ If the same margin of error were valid for HIV, the real maternal prevalence in our sample would be 0.6 and 1.8 percent for HIV and T. pallidum, respectively.

These results are in agreement with other evidence of increased HIV infection rates among Brazilian women of reproductive age, such as the increasing male/female ratio in the number of AIDS cases reported to the Ministry of Health, ${ }^{12}$ and the growing infection rates among the women delivering at the university hospital in Ribeirão Preto. ${ }^{23}$

A prevalence of 0.4 to 0.6 percent in Campinas, and of 1.0 to 1.5 (if cord blood testing detects only two-thirds of maternal infections) in university hospitals should call the attention of medical authorities to the need for HIV screening in pregnant women.

The cost of HIV serology has limited the use of testing during prenatal care in Campinas. Only one university hospital offered this test, but restricted it to pregnant women who referred risk factors for HIV contamination. In view of the results of this study, this attitude may be too passive considering the expansion of the epidemic in the city.

The U.S. Public Health Department, in 1987, and the American College of Obstetricians and Gynecologists, in 1988, recommended that counseling and serologic tests should be offered in all centers assisting high-risk women or groups with increasing seroprevalence.' In New Jersey, a HIV prevalence rate of 4.9/1000 in umbilical cord blood samples (similar to what was found in Campinas) was the justification for offering voluntary HIV testing to all childbearing women and those intending to become pregnant. ${ }^{27}$

The advantage of routine prenatal screening for HIV is that pre- and posttest counseling may provide opportunities for adequate information/education and dialogue leading to genuine behavior modification. Despite the strong emotional impact of the infection diagnosis during pregnancy, there is a benefit in the closer clinical surveillance of the infected pregnant woman and her newborn, which seems to improve the prognosis for seropositive patients. ${ }^{13}$

The similarities of HIV and T. pallidum infections in young women, allied to their close prevalence, suggests the need to treat them in a similar way at the programmatic

Table 6

Value for factors associated with HIV and T. pallidum in multiple logistic regression

\begin{tabular}{lcc}
\hline Factors & HIV & T. pallidum \\
\hline University Hospital & 0.0064 & $<0.0001$ \\
Older Age & N.S. & 0.0115
\end{tabular}


level. For example, the populations at risk and the educational activities to prevent the two infections frequently overlap. The crucial difference is that HIV infection is non-treatable and carries a strong stigma, which justifies the requirement of informed consent prior to HIV testing, while serologic diagnosis of syphilis is routinely done without ethical conflicts.

In light of our results and the above considerations, it is suggested that HIV testing should be included in routine prenatal care in Campinas, as well as in all regions where infection rates have reached intermediate or high levels, such as Santos, Ribeirão Preto, São Paulo and Rio de Janeiro. ${ }^{21.23 .26 .46}$

Studies of pregnant women in the United States have shown that acceptance of HIV testing during the prenatal period reaches only 76 percent, ${ }^{4.5}$ and that infected women are more common among those who refuse to be screened for HIV. ${ }^{35}$

The alternative approach, selectively screening women with risk factors for HIV infection, becomes less efficient, because the higher the prevalence of HIV among the general female population, the higher the proportion of infected women not detected by risk behavior screening. ${ }^{22.34 .50}$ Thus, the clinical-epidemiologic evaluation of risk factors has not been effective in identifying all infected women, leaving $50-66$ percent of positive cases undiagnosed..$^{23.28}$ Therefore, several authors conclude that with prevalence reaching significant levels, routine and universal consented prenatal testing is recommended. ${ }^{48}$

The need and convenience of adopting this strategy depends on periodic reevaluation. The intermediate position of Campinas in the scenario of the epidemic and its populational characteristics suggest that it may serve as a sentinel city for national surveillance of the disease. To this end, repeated prevalence studies among childbearing women should be carried out in Campinas at regular intervals.

The problem is that prevalence studies must be blind and universal to be accurate. The ethics of carrying out blind testing for HIV infection has been questioned because it means not identifying HIV positive women who will deliver and breastfeed their babies without being informed of their condition, or of the precautions they should take with their sexual partner and the newborn. The available alternative should be considered for ethical judgement.

The present situation in Campinas, as well as in the overwhelming majority of births in Brazil, is that women are not given the option of HIV testing. The limiting factors are the lack of available laboratory facilities, the cost of the kits for ELISA and, particularly, of the Western Blot test. As described above, at the time the present study was carried out, only the laboratory of one of the university hospitals was agreeing to do the ELISA test for a selected group of high-risk women attending a prenatal clinic, whereas women delivering in the other hospitals in the city did not have access to HIV testing.

If HIV screening had been available for all patients delivering in Campinas at the time of the study, it would have been unethical to interrupt their routine for research purposes. This was not the case, as no routine was altered during the study period. Still, it could be criticized from an ethical point of view, that as the HIV test had been administered, even throughout a short period, those women and their families could have benefited from information about their condition. This would have required identifying the samples with the name of each woman. For this, we would have had to request the patients' consent, according to accepted ethical principles. Previous experience shows that about 25 percent of the women would not have consented, and that the prevalence of HIV infection is higher exactly in this group..$^{21.28 .31 .50}$ Thus, if we had followed the first procedure we would have failed to accomplish the purpose of the study, namely, to evaluate the real prevalence of HIV infection among women giving birth in Campinas, as those with the highest prevalence might not have been tested.

The ethics of blind surveillance testing has been the subject of profound discussions by working groups in Europe, the United States, Canada and the World Health Organization. An American Journal of Public Health editorial recently concluded that "seroprevalence studies are not only ethically permissible,but their conduct is an ethical resposibility for those responsible for public health". 7 This opinion was endorsed by an editor of Bioetica (a journal published by the Brazilian Federal Council of Medicine), who reviewed the article mentioned above. ${ }^{8}$

Another problem with blind, anonymous serology is that it does not permit the detailed study of sociodemographic factors potentially associated with these infections. Even considering such methodologic restrictions, the present data suggest that there is a link between socio-economic situation and infection, both for HIV and T. pallidum, as all the positive cases were women treated by SUS; none of them were private patients or women with private health insurance. The correlation between HIV infection and poverty has been described by several authors. ${ }^{32.42}$ In the United States, this connection is indirectly observed in the disproportionate prevalence of the infection among blacks and Hispanics. 
Consequently, it appears that HIV infection is another example of the social disadvantage of the poor. The current difficult situation of the public health system in Brazil can not be an excuse to ignore the progressive contamination of the population with HIV. In 1988, the Ministry of Health $(\mathrm{MOH})$ rejected a proposal for universal testing for HIV during prenatal care. Since then, the $\mathrm{MOH}$ has not made a single statement concerning this issue. " Any change in policy should be based on current data on HIV prevalence, such as that provided by this study. We hope that our results may help many women in the future if these results, and those of a later second round, are successful in convincing health authorities of the need for routine HIV screening during prenatal care.

\section{Resumo}

Estudou-se soroprevalência anônima para Virus de Imunodeficiência Humana (HIV) e sifilis através de coleta de sangue de cordão umbilical de 5.815 parturientes, em hospitais de Campinas, SP, por um periodo de seis meses. Foram utilizados testes de ELISA e "Western blot" para diagnóstico de infecção pelo HIV, e VDRL. e TPHA para Treponema pallidum. Mantendo-se o anonimato, colheram-se informaçōes sobre hospital de origem, dividido em universitário (público) e privado, forma de pagamento (seguro social, seguro particular e pagamento direto), idade, situaçāo marital, escolaridade, ocupação e cidade de procedência. A soroprevalência para HIV foi 0,42 percent e para sifilis foi 1,16 percent. Foi encontrada associaçăo entre ambas, isto é, maior prevalência da primeira nas amostras positivas para lues $(p=0,02)$. Após análise por regressão logística, apenas 0 hospital universitário mostrou-se associado à soropositividade para HIV, e a mesma variável e maiores idades se relacionaram à sifilis. Todas as reaçōes positivas para HIV foram encontradas em hospitais universitários ou em pacientes cujos partos foram pagos pelo SUS em hospitais privados. Concluiu-se que a prevalência de infecçâo pelo HIV está se aproximando daquela encontrada através de sorologia para sífilis, afetando pacientes de camadas socioeconômicas menos favorecidas. Sugere-se considerar a indicaçāo de sorologia rotineira e consentida para HIV no pré-natal, quando a população mostrar prevalência de infecção próxima ou maior que 1 percent.

\section{REFERENCES}

1. ACOG-Committee Opinion: Committee on Ethics. Human immunodeficiency virus infection: physicians' responsibilities. Int J Gynecol Obstet 1991;36:340-2.

2. Amaral E, Passini R Jr, Faúndes A, et al. Infecção pelo HIV em Obstetrícia: Revisão e reflexão sobre as várias faces de um problema. Femina 1991;19:104-14.

3. Avins AL, Lo B. To tell or not to tell: the ethical dilemmas of HIV test notification in epidemiological research. Am J Publ Health 1989;79:1544-8.

4. Barbacci M, Repke J, Chaisson R. Routine prenatal screening for HIV infection. Lancet 1991;337:709-11.

5. Barton JJ, O'Connor TM, Cannon MJ, et al. Prevalence of human immunodeficiency virus in a general prenatal population. Am J Obstet Gynecol 1989;160:1316-24.

6. Bayer R, Lumey LH, Wan L. The American, British and Dutch responses to unlinked anonymous HIV seroprevalence studies: an international comparison. AIDS 1990;4:283-90.

7. Bayer R. The ethics of blind HIV surveillance testing. Am J of Public Health 1993;83:496-7.
8. BIOÉTICA. A ética da triagem sorológica não vinculada para o vírus da imunodeficiência humana (HIV). Bioética 1994;2(1): 108 .

9. Blanche S, Rouzioux C, Moscato MLG, et al. A prospective study of infants born to women seropositive for human immunodeficiency virus type 1. $\mathrm{N}$ Engl J Med 1989;320:1643-8.

10. Ministério Da Saúde, Brasil. Pré-natal de baixo risco. Normas e Manuais Técnicos. Brasília 1986.

11. Ministério Da Saúde, Brasil. AIDS - Recomendações Técnicas e Aspectos Éticos. Brasília 1988.

12. Ministério Da Saúde, Brasil. In: Boletim Epidemiológico AIDS. Ano VI, $\mathrm{N}^{\circ} 4$, Brasilia, Semana Epidemiológica. May 14-17, 1993.

13. Buchbinder S, Katz M, Hessol N, et al. Health long-term positive: men infected with HIV for more than 10 years with CD4 counts $>500$ cells. In: Final Program \& Oral Abstracts of the VIII International Conference On Aids, Amsterdam, 1992:tU41(tuc O572).

14. Center For Disease Control. Public health service guidelines for counseling and antibody testing to prevent HIV infection and AIDS. M M W R 1987;36:509-15. 
15. Center For Disease Control. Recommendations for prevention of HIV transmission in health-care settings. M M W R 1987; 36(suppl:1S-18S).

16. Center For Disease Control. Update: universal precautions for prevention of human immunodeficiency virus, hepatitis $\mathrm{B}$ virus, and other blood-borne pathogens in health-care settings. M M W R 1988;37:377.

17. Center For Disease Control. Interpretation and use of the Western blot assay for serodiagnosis of human immunodeficiency virus Type 1 infections. M M W R 1989;38(S-7):1.

18. Chateauvert M, Duffie A, Gilmore N. Human immunodeficiency virus antibody testing: Counseling guidelines from the Canadian Medical Association: Ottawa:Can. Med. Assoc, 1990.

19. Diniz EM. Aspectos epidemiológicos e sorológicos da Síndrome de Imunodeficiência Adquirida em população de alto risco para doenças sexualmente transmissíveis. São Paulo 1990. (Thesis - School of Medicine, Universidade de São Paulo)

20. Dondero TJ, Curran JW. Serosurveillance of Human Immunodeficiency Virus infection. Am J Publ Health 1991;81:561-2.

21. Duarte G, Pinhata MM, Pasti MJ, et al. Problemas práticos na determinação da prevalência e assistência às parturientes com sorologia positiva para HIV. In: XV Congresso Brasileiro de Ginecologia e Obstetrícia, São Paulo, 1989.

22. Duarte G, Mussi-Pinhata MM, Del Lama J., et al. Valor de questionário específico na identificação de parturientes de risco para infecção pelo vírus da imunodeficiência humana (HIV). J Bras Ginecol 1991;101:169-74.

23. Duarte G, Quintana FM, Marana HRC, et al. Does the diagnosis of other STD identify parturients at risk for HIV infection? In: Final Program \& Oral Abstract of the VIII International Conference On Aids, Amsterdam, 1992:B171(PoB3508)

24. European Collaborative Study. Children born to women with HIV-1 infection: natural history and risk of transmission. Lancet 1991;337:253-61.

25. European Collaborative Study. Risk factors for mother-tochild transmission of HIV-1. Lancet 1992;339:1007-1012.

26. Giraldes PR, Santos MC, Rivetti PS, et al. Pesquisa de anticorpos anti-HIV pelo teste ELISA na rotina pré-natal. Rev Bras Med 1989;46:106-8.

27. Gwinn M, Pappaioanou M, George JR, et al. Prevalence of HIV infection in childbearing women in the United States: Surveillance using newborn blood samples. JAMA 1991;265:1704-8.

28. Hassig SE, Kinkela N, Nsa W, et al. Prevention of perinatal HIV transmission: are there alternatives to prepregnancy serological screening in Kinshasa, Zaire? AIDS 1990;4:913-16.

29. Henderson DK, Fahey BJ, Willy M, et al. Risk of occupacional transmission of immunodeficiency virus Type 1 (HIV-1) associated with clinical exposure: a prospective evaluation. Ann Intern Med 1990;113:740-6.
30. Hoff R, Berardi VP, Weiblen BJ, et al. Seroprevalence of human immunodeficiency virus among childbearing women. Estimation by testing samples of blood from newborns. N Engl J Med 1988; 318:525-30.

31. Hull HF, Bettinger CJ, Gallaher MM, et al. Comparison of HIV-antibody prevalence in patients consenting to and declining HIV-antibody testing in an STD clinic. JAMA 1988;260:935-8.

32. Krueger LE, Wood RW, Diehr PH, et al. Poverty and HIV seropositivity: the poor are more likely to be infected. AIDS 1990;4:811-14.

33. Landesman S, Minkoff H, Holman S, et al. Serosurvey of human immunodeficiency virus infection in parturients. Implications for human immunodeficiency virus testing programs of pregnant women. JAMA 1987;258:2701-3.

34. Lindsay MK, Adefris W, Peterson HB, et al. Determinants of acceptance of routine voluntary Human Immunodeficiency Virus testing in an inner-city prenatal population. Obstet Gynecol 1991;78:678-80.

35. Lindsay MK, Peterson HB, Willis S, et al. Incidence and prevalence of human immunodeficiency virus infection in a prenatal population undergoing routine voluntary human immunodeficiency virus screening, July 1987 to June 1990. Am J Obstet Gynecol 1991;165:961-4.

36. Mann JM. Global AIDS in the 1990's. J Acq Immun Def Synd 1990;3:348.

37. Miller JL, Meyer PG, Parrott NA, et al. A study of the biologic falsely positive reactions for syphilis in children. J Pediatr 1960;57:548-52.

38. Organisación Panamericana De La Salud. Relatório da I Reunião Latinoamericana sobre SIDA/AIDS MaternoInfantil na Região das Américas. São Paulo, 1990.

39. Organisation Mondiale De La Santé. Pandemie d'infection a VIH \SIDA: situation actuelle et tendances futures. Recapitulation. Geneva, January 1992.

40. Piot P, Plummer FA, Mhalu FS, et al. AIDS: An International Perspective. Science 1988;239:573-9.

41. Piot P, Laga M, Ryder R, et al. The global epidemiology of HIV infection: continuity, heterogeneity and change. J Acq Immun Def Synd 1990;3:403-12.

42. Piot P. Epidemiology of STDs: State-of-the-Art. In: Final Program \& Oral Abstracts of the VIII International Conference On Aids, Amsterdam, 1992.

43. Porto AGM. Prevalence of acquired immunodeficiency syndrome detected during prenatal care of a population of low socio-economic status. Am J Obstet Gynecol 1991;164:705-6.

44. Rawstron SA, Bromberg K. Comparison of maternal and newborn serologic tests for syphilis. A J D C 1991;145:1383-8.

45. Ryder RW, Nsa W, Hassig SE, et al. Perinatal transmission of the human immunodeficiency virus Type 1 to infants of seropositive women in Zaire. N Engl J Med 1989;320:1637-42.

46. Schechter M. AIDS III - Mal ataca 8 em cada mil gestantes. Súmula Radis. Fiocruz. Ano VIII, junho, 1991. 
47. Slutkin G, Chin J, Tarantola D, et al. Sentinel surveillance for HIV infection: a method to monitor HIV infection trends in population groups. Global Programme on AIDS, W.H.O. In: IV International Conference On Aids, Geneva, June 1988.

48. Slutkin G, Chin J, Tarantola D, et al. Use of HIV surveillance data in National AIDS Control Programmes. A review of current data use with recommendations for strengthening future use. Global Programme on AIDS. World Health Organization, Geneva, 1990.

49. Tovo PA, Martino M. Epidemiology, clinical features and prognostic factors of pediatric HIV infection. Italian multicentre study. Lancet 1988;5:1043-5.
50. Wenstrom KD, Zuidema LJ. Determination of seroprevalence of human immunodeficiency virus infection in pregnant womean by non-anonimous versus anonimous testing. Obstet Ginecol 1989;74:558-61.

51. World Health Organization. Current and future dimensions of the HIV/AIDS pandemic: A capsule summary. Geneva, April 1991.

52. World Health Organization-Surveillance, Forecasting And Impact Assessment Unit (SFI). Update: AIDS cases reported to Global Programme on AIDS. Geneva, July 1991. 